Proceedings of the New Zealand Grassland Association, 47: 99.105 (1986)

\title{
LOLIUM ENDOPHYTE AND SHEEP PERFORMANCE ON PERENNIAL RYEGRASS CULTIVARS
}

L. R. FLETCHER

Grasslands Division, DSIR, Lincoln

\section{ABSTRACT}

Some effects of lolium endophyte (Acremonium loliae) on sheep production were evaluated using pure swards of high $(50 \%>)$ and low $(<5 \%)$ endophyte Nui and Ariki ryegrass. The proportion of infected tillers in high endophyte treatments increased by $19 \%$ in 15 months. Ryegrass staggers occurred on both high endophyte ryegrasses - being slightly worse on Nui. The peak ryegrass staggers outbreak did not coincide with peak endophyte mycelium concentration in ryegrass plants. Hoggets grazing the low endophyte ryegrasses had a $1.6 \mathrm{~kg}$ advantage in liveweight gain in spring, when allowances were equal, but fewer sheep grazing days. In summer and autumn sward damage by Argentine stem weevil, drought and over-grazing eliminated low endophyte Ariki treatments and reduced herbage production from low Nui to $70 \%$ of high endophyte Nui. Tiller densities in low endophyte treatments were $28 \%$ of those in high endophyte treatments. High endophyte Ariki had the highest overall production: $7.8 \mathrm{t} / \mathrm{ha}$ of herbage and $15 \mathrm{~kg} / \mathrm{head}$ liveweight gain compared with $6.9 \mathrm{t} / \mathrm{ha}$ and $12.5 \mathrm{~kg} / \mathrm{head}$ for high endophyte Nui and $4.7 \mathrm{t} / \mathrm{ha}$ and $9 \mathrm{~kg} / \mathrm{head}$ for low endophyte Nui. Differences in production due to endophyte highlight the need for caution in interpreting results from trials when endophyte status of ryegrass is unknown.

Keywords: Lolium endophyte, Acremonium Ioliae, ryegrass staggers, Lolium perenne, live weight gain, pasture production, Ariki, Nui.

\section{INTRODUCTION}

Research into the relationships between lolium endophyte (Acremonium loliae), perennial ryegrass and animal production has exposed several contradictory consequences of endophyte presence. The presence of endophyte has been linked with the neuromuscular disorder ryegrass staggers, low liveweight gains in sheep during spring and reduced serum prolactin levels in sheep (Fletcher and Harvey 1981, Fletcher 1982, 1983, Fletcher and Barrell 1984). Conversely improved ryegrass persistence and production during and after summer drought, owing to reduced Argentine stem weevil (Listronotus bonariensis) damage, has also been linked to endophyte presence (Prestidge et al. 1982, Mot-timer et al. 1982, Gaynor and Hunt 1983). Under optimum plant growth conditions acremonium loliae has also been shown to increase plant growth (Latch et al. 1985).

Although the use of alternatives to perennial ryegrass is increasing, it is still the major grass species sown in permanent pastures. With the lolium endophyte as an added dimension, the choice of perennial ryegrass will depend on climate and the individual farmers requirements for his production system. A high quality, high endophyte, persistent ryegrass could reduce the need for frequent pasture renewal or oversowing, a significant cost in pastoral farming, but will not alleviate the highly underated and costly problem of ryegrass staggers.

Grasslands Nui ryegrass (Lolium perenne L.) is one of the more common cultivars used today, yet results with its quality, production and persistence have been variable.

These variations are now accepted as being due to different levels of endophyte (Gaynor and Hunt 1983).

Grasslands Ariki ryegrass Lolium [(multiflorum $\times$ perenne $) \times$ perenne ] was released with good credentials of being resistant to Argentine stem weevil attack and having better quality and higher production than Grasslands Ruanui, (Barclay 1963, Bascand 1963, Lancashire and Ulyatt 1975). Later it received a reputation for poor production 
and persistence especially in drought (Vartha 1978).

In lolium endophyte/animal production research a better understanding of the mechanisms involved is necessary if we are to successfully manipulate the endophyte for our benefit. This paper discusses the effects, on sheep performance, of lolium endophyte in pure swards of Nui and Ariki ryegrass.

\section{METHODS}

Three 0.2 ha paddocks each of Ariki high endophyte ryegrass $(80 \%>)$, Ariki low endophyte $(<5 \%)$, Nui high endophyte ryegrass $(80 \%\rangle)$ and Nui low endophyte $(<5 \%)$ were break grazed by Coopworth ewe hoggets on a 3 week rotation from 21 September 1984 until 15 April 1985. All ryegrasses had been sown at $20 \mathrm{~kg} / \mathrm{ha}$ as pure swards, with any volunteer clover sprayed out. Each paddock was grazed in 3 breaks of 3,2 and 2 days duration. The trial was divided into two stages. During stage 1 , from beginning of the trial until 4 January, the stocking rate was adjusted above a minimum of 12 "test" sheep per treatment (20/ha) to equalise daily herbage allowance per head over all treatments. Adjustments were made at each break and sheep grazing days recorded. Break size, grazing duration and rotation length remained constant across treatments throughout the trial.

Stage 2 began on 5 January when adjustments to equalise daily allowances became unrealistic because of greatly reduced herbage production from low endophyte ryegrasses, a result of Argentine stem weevil damage (S. L. Goldson pers. corn.), drought and unavoidable overgrazing. Sheep numbers from that point were held constant at the 12 "test" animals per treatment until the end of the trial, creating large differences in herbage allowance between the high and low endophyte treatments. The low endophyte Ariki treatments had to be destocked on 27 February, as herbage production was so low it could no longer sustain acceptable animal performance.

All sheep were assessed at intervals for ryegrass staggers symptoms using the criteria of Keogh (1973). The sheep on each treatment were weighed every 7 days, and herbage was measured before and after grazing of each break. The proportion of ryegrass tillers containing endophyte was measured from 30 randomly selected tillers on all 12 paddocks using the Eliza technique (Musgrave 1984). The concentration of endophyte mycelium per unit of plant tissue was measured weekly in high endophyte Nui treatments throughout the trial and from January 29 in high endophyte Ariki, from the bulk of 30 randomly selected tillers. Only the sheaths of the last two expanded leaves on each tiller were used. The number of live ryegrass tillers per metre 2 in each paddock was determined from counts on $8 \times 1 / 4 \mathrm{~m}$ drill rows, in April.

The exceptionally dry conditions throughout the trial had a marked effect on results. Rainfall was below average and evaporation high (Figure 1d). To ensure a continuing supply of herbage, nitrogen as calcium ammonium nitrate was applied at 35 units of N/ha on 10 September and 40 units on 9 October followed each time by 40 and $30 \mathrm{~mm}$ of irrigation respectively, and two irrigations each of $100 \mathrm{~mm}$ were applied on 1 February and 9 February.

TABLE 1: Live ryegrass tillers containing (Acremonium Loliae)

\begin{tabular}{lcccc}
\hline Samble Date & \multicolumn{3}{c}{ Ariki } & \multicolumn{2}{c}{ Nui } \\
\cline { 2 - 5 } & Low & High & Low & High \\
\hline Dec. 1983 & 0 & 65 & 0 & 69 \\
Mar. 1985 & 0 & 82 & 1.7 & 90 \\
SED & & 5.6 & & 7.8 \\
\hline
\end{tabular}




\section{SEASONAL PATTERNS}
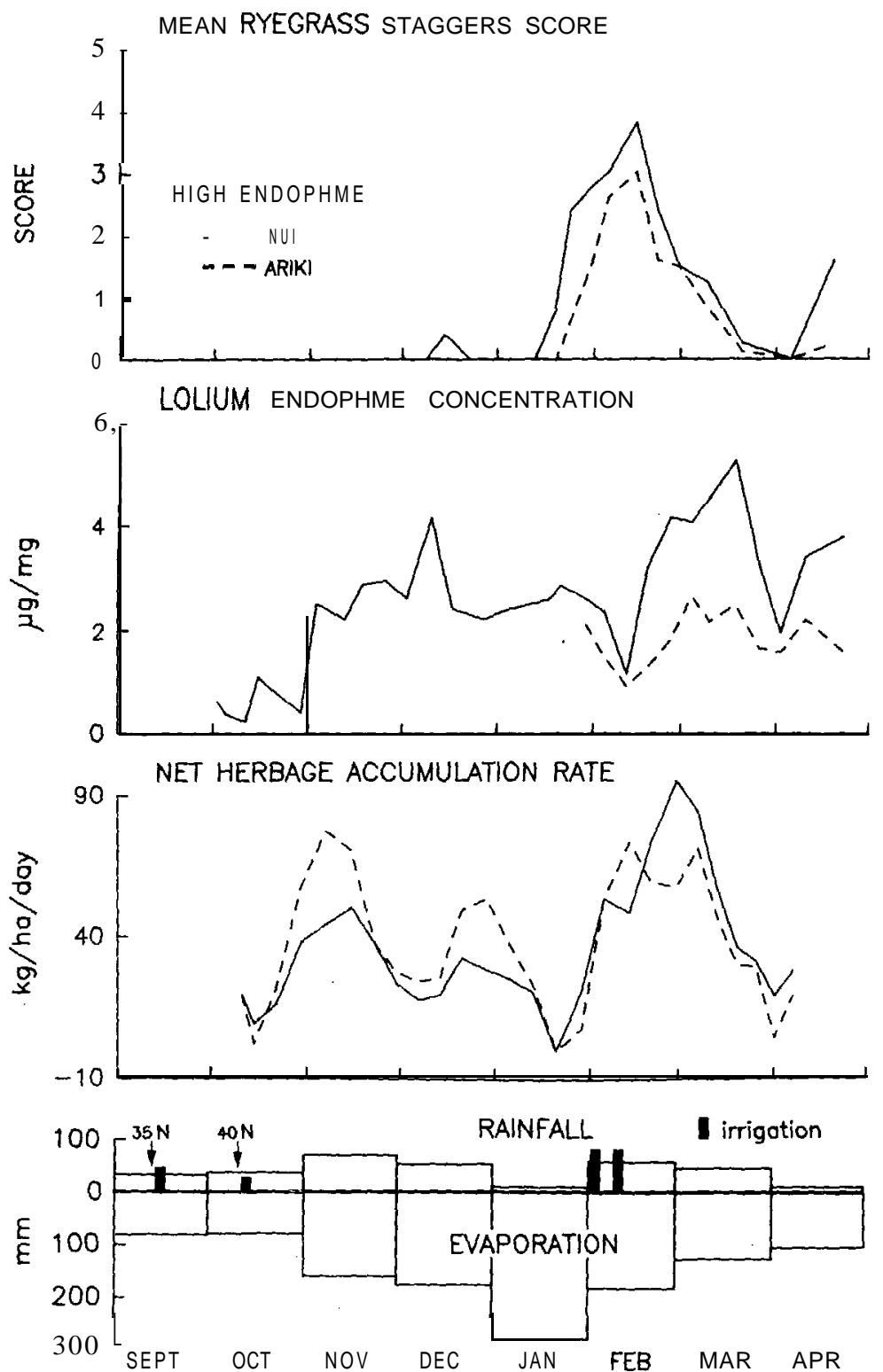

FIGURE 1: Seasonal Patterns:

(a) Ryegrass staggers, mean score (Keogh 1973) of 12 sheep/treatment.

(b) Lolium endophyte concentration $\boldsymbol{\mu} \mathbf{g}$ wet weight of mycelium $/ \mathbf{m g}$ dry weight of plant using ELISA (Musgrave 1984), week ly samples.

(c) $\mathrm{N}$ et herbageaccumulation rate. $\mathrm{kg} / \mathrm{ha} / \mathrm{day}$ (growth rate)weekly cuts pre-and post-grazing on 3 week regrowth.

(d) Rainfall and Evaporation, rainfall $\mathrm{mm}$ and evaporation $\mathrm{mm}$ (open pan), at Lincoln. 


\section{RESULTS AND DISCUSSION}

The term 'level of endophyte' is ambiguous without qualification. The proportion or percentage of plants or tillers in a ryegrass pasture which have endophyte present must be clearly distinguished from the concentration of endophyte mycelium per unit of plant tissue. The percentage of tillers containing endophyte measured on two occasions are shown (Table 1). The percentage increased by $21 \%$ in Nui and $17 \%$ in Ariki over 15 months which included two summers. The increase is most likely explained by the combined effects of drought, overgrazing and selective Argentine stem weevil attack, killing endophyte free plants. The seasonal pattern of endophyte concentration per unit of plant tissue in Nui ryegrass follows the pattern of ryegrass growth with an approximate 10 day time lag by the endophyte (Figure $\mathrm{lb}$ and $\mathrm{lc}$ ). The close association of endophyte concentration with plant growth could be explained by the extremely close association of the endophyte with the host ryegrass plant. Concentrations shown (Figure lb) take no account of the dead and senescing material also available to grazing sheep. Endophyte concentrations in Ariki, taken from 29 January, were lower than for Nui over the same period but this could be explained by lower growth rate of Ariki over this period and the $8 \%$ difference in the number of infected tillers.

There was no evidence of ryegrass staggers on low endophyte ryegrasses during the trial, but it was first noted in sheep grazing Nui high endophyte ryegrass in mid. December when 3 sheep were slightly affected briefly. The main outbreak of ryegrass staggers occurred from late January until late March with a slight reoccurrence in mid-April. Sheep grazing on Nui were more severely affected than those on Ariki at all times. The most severe outbreak of ryegrass staggers did not peak at the seasonal peak of endophyte concentration (Figure la and $\mathrm{lb}$ ) but actually peaked in a trough of measured endophyte concentration. The beginning of the main outbreak coincided with the period of lowest rainfall and highest evaporation and resultant lowest plant growth rate, all indicative of plant stress (Figure la and Id). Ryegrass staggers began to improve shortly after heavy irrigation and rain resulting in a rapid increase in grass growth and endophyte growth.

Toxicity in endophyte "infected" ryegrass, indicated by ryegrass staggers, may be affected more by moisture stress on host ryegrass plant tissue than concentration of endophyte mycelium in the host. Ryegrass staggers is often associated with close grazing of ryegrass (Keogh 1973). Unavoidable close grazing is often the result of lower plant growth rates and consequent low herbage availability. The mainoutbreak in this trial occurred over the period of highest grazing intensity.

Sheep grazing low endophyte ryegrasses had a small but significant advantage over those on high endophyte in liveweight gain in stage 1 when allowances were equal (Figure 2). Standard errors at the maximum liveweight difference in stage 1 were \pm $0.31 \mathrm{~kg}$ for low endophyte Nui andf $0.29 \mathrm{~kg}$ for high endophyte Nui. An earlier trial with young sheep set stocked on these swards gave similar results (Fletcher and Barrell 1984). Herbage allowances during stage 1 varied from $2.5 \mathrm{~kg} / \mathrm{head} /$ day to 3.8 $\mathrm{kg} / \mathrm{hd} /$ day and the total number of sheep grazing days per hectare at the end of stage 1 was 947, 1146, 925 and 1103 for Ariki low endophyte, Ariki high endophyte, Nui low endophyte and Nui high endophyte respectively.

Sheep gained more weight on low endophyte ryegrasses and more on Ariki than Nui during stage 1 . It cannot be determined how long the 'quality' advantage to low endophyte ryegrass would continue since low 'pasture' production from low endophyte ryegrasses made allowance adjustments impracticable. The decline in sheep liveweights in late November-early December resulted from decreased pasture production in November (Figure lc) and consequent lower allowances and closer grazing. Sheep grazing Nui treatments lost more weight than those on Ariki during this period when allowances were equal. 


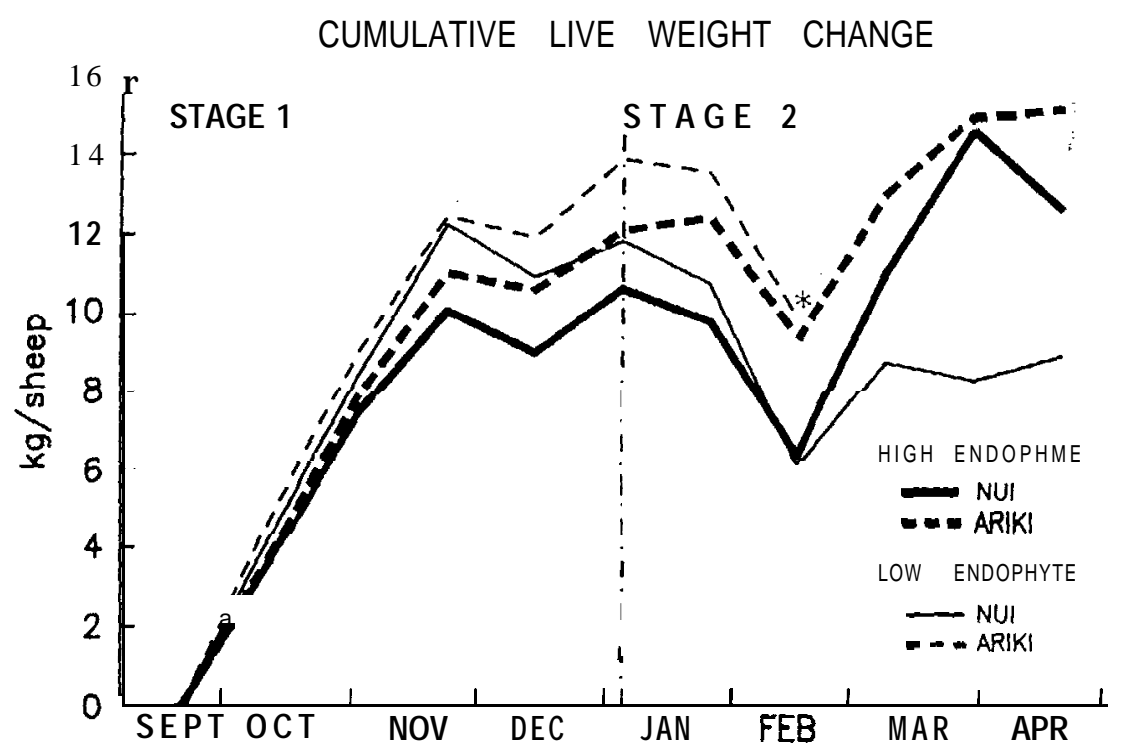

FIGURE 2: Cumulative liveweight change: mean liveweight change ( $\mathrm{kg} / \mathrm{head})$, of 12 sheep per treatment, over 3, weekly weighings.

Stage 1: herbage allowances equalised for all treatments.

Stage 2: herbage allowances not adjusted.

^ Low endophyte Ariki treatment discontinued due to poor herbage production.

During stage 2 from January 4 until the end of the trial allowances were not adjusted and liveweight changes over this period are a reflection of quantity and quality of herbage on offer. Allowances over this period ranged from $0.85-1.6 \mathrm{~kg} / \mathrm{head} / \mathrm{day}$ for low endophyte Ariki, 2.9-3.9 for high endophyte Ariki, 1.7-1.9 for low endophyte Nui and 2.9-4.6 for high endophyte Ariki.

During January and February following a severe drought (Figure Id) low herbage allowances with little green material, resulted in a further weight loss in sheep on all treatments, but again it was greater on Nui. The greater weight loss in sheep on low endophyte treatments over this period was the result of lower allowances on these treatments. Ariki low endophyte treatments were destocked in mid-February and pasture production was so low until the end of the trial that they could not be restocked.

The marked increase in liveweight gains from mid-February through March followed irrigation (Figure Id) and increased herbage production. Sheep on high endophyte Nui treatments gained more weight than those on high endophyte Ariki as result of the better ryegrass growth (Figure $\mathrm{lb}$ ). When allowances decreased again in April resulting in closer grazing, sheep on high endophyte Nui lost weight while their Ariki counterparts continued to gain slightly. The relatively poor performance of low endophyte Nui sheep throughout stage 2 is a reflection of poor herbage production (Table 2). The additional sheep grazing days during stage 1 must be considered in conjunction with liveweight gains when assessing sheep production from any treatment.

High endophyte ryegrasses show a marked advantage in herbage production over low endophyte ryegrasses at end of the trial period, particularly for high endophyte Ariki (Table 2). Herbage growth on low endophyte Ariki was negligeble from the end of February until the end of trial. The margin in herbage accumulation between high and low endophyte ryegrasses became significant and increased markedly from December. 
TABLE 2: Live tiller density $00 / \mathrm{m}^{24} / 4 / 85$ (Tiller counts from $8 \times 1 / 4 \mathrm{~m}$ drill rows) and net herbage accumulation (Herbage cuts from 3 week regrowth).

\begin{tabular}{|c|c|c|c|c|c|c|}
\hline & \multicolumn{2}{|c|}{$\begin{array}{l}\text { Tiller density } \\
{ }^{\circ} 00 / \mathrm{m}^{2}\end{array}$} & \multicolumn{4}{|c|}{$\begin{array}{c}\text { Net herbage accumulation } \\
\text { t/DM/ha }\end{array}$} \\
\hline & & S E & $\begin{array}{l}23 \text { Oct. . } \\
24 \text { Dec. }\end{array}$ & $\begin{array}{l}25 \text { Dec. . } \\
27 \text { Feb. }\end{array}$ & $\begin{array}{l}28 \text { Feb. . } \\
15 \text { Apr. }\end{array}$ & Total \\
\hline \multicolumn{7}{|l|}{ Ariki } \\
\hline High endo. & 12.6 & 1.0 & $3.6 \mathrm{a}$ & $3.20 \mathrm{a}$ & $1.0 \mathrm{a}$ & 7.8 \\
\hline $\begin{array}{l}\text { low endo. } \\
\mathrm{Nui}\end{array}$ & 2.1 & 1.5 & $2.8 \mathrm{a}$ & $0.85 \mathrm{~h}$ & $N / A$ & $N / A$ \\
\hline high endo. & 9.2 & 1.0 & $2.5 \mathrm{~b}$ & $3.10 \mathrm{a}$ & $1.3 \mathrm{a}$ & 6.9 \\
\hline low endo. & 3.9 & 0.2 & $2.1 \mathrm{~h}$ & $1.40 \mathrm{~b}$ & $1.2 \mathrm{a}$ & 4.1 \\
\hline
\end{tabular}

$\mathrm{a}, \mathrm{b} \_$within columns values followed by the same letter are not different at $\mathrm{P}<0.05$

Lower herbage production on low endophyte treatments (Table 2) was most likely due to the combined effects of Argentine stem weevil damage (S. L. Goldson pers. comm.), possibly other insects (D. L. Gaynor pers. comm.), drought and associated but unavoidable overgrazing. This damage resulted in high death rate of tillers and plants (Table 2). It is possible that endophyte presence increased plant growth in the high endophyte treatments. In this trial Ariki was both the highest producing and most persistent, and lowest producing and least persistent, depending entirely on its endophyte status. These results suggest that both the good and poor reputations of Ariki are warranted.

The 'pastures' in this trial were pure swards and inclusion of clover could influence the results in a farming situation. Problems have been experienced in establishing clover with high endophyte Ariki (Sears and Brougham 1963, T.J. Fraser pers. corn.). Sears and Brougham (1963) however suggest a reduction in ryegrass seeding rate will improve clover establishment.

\section{SUMMARY}

Intermediate endophyte levels or blends are not a viable option or compromise in the lolium endophyte dilemma as the percentage of plants with endophyte is likely to become high in a relatively short time.

Although the endophyte gives ryegrass the potential to cause poorer liveweight gains, ryegrass staggers and gives protection against Argentine stem weevil attack, the affects and there magnitude can be modified by environmental and management factors. This may also be true of ryegrass without endophyte.

If drought and pasture persistence are not a problem then advantages in higher spring animal weight gains from low endophyte ryegrass may make it an attractive option.

In dry areas where pasture persistence is a problem and pasture renewal is a significant cost, high endophyte ryegrass will be more persistent but have the potential to cause ryegrass staggers and poorer animal performance in spring.

If high endophyte ryegrass is chosen there may still be room for compromise in the endophyte dilemma. Endophyte may be regarded as an added dimension and when combined with a perennial ryegrass cultivar with high genetic quality factors the detrimental effects of lower liveweight gains may be reduced.

Ariki appears to have this potential.

The production differences between high and low endophyte Ariki in this trail highlight the dangers in interpreting results from trials involving perennial ryegrass where the endophyte status is unknown. It is imperative that the endophyte status of 
ryegrass seed including endophyte viability is known when comparing ryegrass cultivars or ryegrass and other species. Farmers may need tore-evaluate their choice of ryegrass on these grounds.

Apart from replacing high endophyte ryegrass with ryegrass without endophyte or an alternative species, there does not appear to be any immediate solution to the often under-rated and costly problem of ryegrass staggers.

\section{ACKNOWLEDGMENTS}

The author is grateful for technical assistance of Mr. D. M. Moore, L. Sutherland, I J. Baird and the constructive criticisms of Mr. T. J. Fraser and Dr. E. W. Vartha and assistance of Miss E Stevenson in analysis.

\section{REFERENCES}

Barclay, P. G. 1963. Proc. N.Z. Grassid. Ass. 25: 129.137

Bascand, L. D. 1963. Ibid 25: 137-144.

Gaynor, D. L.; Hunt, W. F. 1983. Ibid 44: 257-263.

Fletcher. L. R.; Harvey 1. C. 1981. N.Z. Vet. J. 29: 185-186

Fletcher, L. R. 1982: N.Z. J. exp. Agric. IO: 203-207

Fletcher, L. R. 1983: Proc. N.Z. Grossld. Ass. 44: 237-239.

Fletcher, L. R ; Barrell, G. K. 1984: N.Z. Vet. J. 32: 139140

Keogh, R. G. 1973: N.Z. J exp. Agric. 1:51-57.

Lancashire, J A.; Ulyatt, M. J. 1975: N.Z. J. agric. Res. 18: 97-100

Latch, G. C. M.; Hunt, W. F.; Musgrave, D. R. 1985. Ibid 28: 165-168.

Mortimer, P. H.; Fletcher, L. R.; di Menna, M. E.; Harvey, 1. C.; Smith, G. S.; Barker, G. M.; Gallagher, R. T.; White, E. P. 1982: Proc, Ruakura Fmrs Conf. 34: 71-74.

Musgrave, D. R. 1984 N.Z. J. agric. Res. 27: 283-288.

Prestidge, R. A.; Pottinger, R P.; Barker, G. M. 1982: Proc. 35th N.Z. Weed Pest Cont. Conf. 119.122. Sears, P. D.; Brougham, R. W. 1963: Proc. N.Z. Grassld Ass. 25: 148 153.

Vartha, E. W. 1978. N.Z. J. exp. Agric. 6: 157160. 